\title{
Strategies to Improve the Competence of Public Service Officials in Nigeria
}

\author{
Bernard Oladosu Omisore, Ph.D \\ Centre for Management Development, Shangisha, Lagos, Nigeria \\ Email: bernardoladosu@yahoo.com
}

Accepted: November 09, 2013

doi:10.5296/ jpag.v3i4.4929 URL: http://dx.doi.org/10.5296/ jpag.v3i4.4929

\begin{abstract}
Public services play a central role in the well-being, sustainability and growth of communities, cities, and nations. Nigeria's quest to attain the United Nation's Millennium Development Goals (MDGs) will be a mirage without the public officers taking the driving seat to lead the process. Improvement in the capacity and ability of public service officials can be harnessed to improve a range of public services (e.g. health, policing, education, environment, local government, policy-making, etc.). The changing global economy, technology, politics, and increased expectations for government performance demand new attention to the complex set of public skills and capacity. Public officials are experiencing intense pressures emanating from increasing global integration - economic, political, social and cultural.

New technology, new ways of organizing work, new means of delivering services and an increasing reliance on temporary employment have redefined the nature of public service. Meeting all these challenges requires a unique combination of knowledge, skills, abilities, traits and behaviours, effective human resource development policies and strategies to nurture those competencies. Against the background problems of persistent low performance of the Nigerian Public Service and the inability of the sector to deliver efficient and effective public goods and services, the Obasanjo civilian administration (1999 - 2007) identified the need for a more comprehensive and wide-ranging public sector reforms as part of its overall development framework.

The success of the plethora of reform programmes of the federal government of Nigeria will largely depend on the quality of its workforce (public officers) that is statutorily charged with the responsibility to analysing, implementing, monitoring and evaluating policies and programmes of government. For example, if the service fails to deliver to certain standards, a country can lose its competitiveness, lose its direct investments and can lose its talented individuals to other countries (brain drain). While the choices are not always this simple, the
\end{abstract}


ramifications and repercussions of a non-performing public sector are great in its impact and implications to the nation, its people, and its economy. To be able to deliver such levels of service, on the current scale and complexity, the fundamental personal qualities of those who deliver the service becomes imperative and vital.

The objective of this paper is to identify strategies for improving the competence of public service officials in Nigeria with a view to moving public management beyond bureaucracy and promote greater economy, efficiency and effectiveness in public service delivery.

Keywords: Public Service, sustainability, Millennium Development Goals (MDGs)

\section{Introduction}

Competent employees are the main resource of any organization in acquiring a competitive advantage. Land, buildings or materials do not yield company productivity, rather, it is 'people capital' that runs a business and produces value from existing resources. Hay Group (2004) points out that an organization's best source of competitive advantage lies with its employees. Strategies, business models, products and services can all be copied by competitors, but talented and competent employees represent a sustainable source of differentiation. The demand for effective and competent employees continuously increases in both public and private organizations because a dynamic global marketplace and increasing foreign competition has compelled organizations to become more effective and flexible in response to the rapidly changing environment. As a result, this is a suitable time to assess human resource management (HRM) practices that can augment organizational performance in public sector organizations (Gould-Williams, 2003).

Organizations try to increase their capabilities by investing more in training and management development, and Ichniowski et al. (1996) state that HRM practices have a greater effect on organizational performance than on individual performance. Moreover, human resource development encourages competency development by forming opportunities within the organization for employees to develop their competencies for both their own benefit and the benefit of others (Rao, 2000a; Rodrigues \& Chincholkar, 2005).

The term competency was probably first introduced to psychology literature in 1973 when David McClelland argued in his article 'Testing for competence rather than for intelligence' that traditional tests of academic aptitude and knowledge content in fact predicted neither job performance nor success in life. Thus, the quest for theory and tools that could reliably predict effectiveness in the workplace began (McClelland, 1973). In 1982, it was Boyatzis who first drew together comprehensive data that had been collected in the USA using the McBer \& Company 'Job Competence Assessment' method. Since then, competency has become a significant factor in HR development practices (Simpson, 2002).

The word competency comes from a Latin word meaning "suitable" (Bueno \& Tubbs, 2004). Boyatzis (1982) defines competency as "an underlying characteristic of a person which results in effective and/or superior performance in a job” (p. 97). 
According to Boyatzis (1982), a job competency represents ability. An individual's set of competencies reflect their capability or what they can do. A job competency may be a motive, trait, skill, aspect of one's self-image or social role, or a body of knowledge that an individual uses, and the existence and possession of these characteristics may or may not be known to the individual. Similarly, Mitrani et al. (1992) state that competencies could be motives, traits, self-concepts, attitudes or values, content knowledge, or cognitive or behavioural skills.

A competency is an individual characteristic that can be measured or counted reliably and that can be shown to differentiate significantly between superior and average performers, or between effective and ineffective performers. Meanwhile, competency can be described as a set of behaviour patterns that an incumbent needs to bring to a position in order to perform its tasks and functions in the delivery of desired results or outcomes (Bartram, et. al, 2002; Woodruffe, 1992). Spencer and Spencer (1993) viewed competency as "an underlying characteristic of an individual that is causally related to criterion-referenced effective and/or superior performance in a job or situation".

They identified five types of competency characteristics consisting of motives, traits, self-concept, knowledge and skills. First, motives are the things that an individual consistently thinks about or wants that stimulate action. Motives drive, direct and select behaviour toward certain actions or goals and away from others. Second, traits are physical characteristics and consistent responses to situations or information. Third, self-concept is an individual's attitudes, values or self-image. Fourth, knowledge is the information that an individual has in specific content areas. Finally, skill is the ability to perform a certain physical or mental task. Knowledge and skill competencies tend to be visible and relatively surface characteristics, whereas self-concept, traits and motive competencies are more hidden, deeper and central to personality. Knowledge and skill competencies are relatively easy to develop and training is the most cost-effective way to secure those employee abilities (Spencer \& Spencer, 1993).

In other words, visible competencies such as knowledge and skills may be somewhat technical competencies basically required by the job, whereas hidden competencies such as self-concept, traits and motives are behavioural competencies that drive an individual's performance on the job. Boyatzis (1982) states that motive and trait competencies have the most direct impact on self-concept and also have an impact on skills. The United Nations Industrial Development Organization (UNIDO, 2002) defines competency as a set of skills, related knowledge and attributes that allow an individual to perform a task or activity within a specific function or job. If an individual possesses these three elements of competency they can effectively perform duties as required by the specific job.

From the wide range of related literature, the definition of competency can be summarized as an underlying characteristic of an individual that is causally related to criterion-referenced effective and/or superior performance in a job or situation. Job competency is a set of behaviour patterns that a job incumbent needs to bring to a position in order to perform its tasks and functions with competence. A job competency can be a motive, trait, skill, self-concept, body of knowledge or an attribute that allows an individual to perform a task or 
activity within a specific function or job. Skills and knowledge are surface or technical competencies that can be developed easily by training. On the other hand, motives, traits and self-concept are hidden or behavioural competencies that are difficult to develop. Traditionally, it is essential for an individual to possess the required technical competencies at a threshold level in order to adequately perform their job. However, the changing environment and diverse workforce has resulted in behavioural competencies becoming crucial as the greatest determinants of an individual's performance. Thus, in order to be effective in a job, individuals needs to possess or acquire both technical and behavioural competencies and use these together in performing their tasks.

\subsection{Public Sector Reforms in Nigeria}

The problem of the Nigerian public service is not the lack of reforms/policies, neither is it the lack of critical personnel, far from it. Rather, our problem is that of too many reforms/policies without the much needed political will for their implementation. As a matter of fact, the history of public sector reforms in Nigeria dates back to the pre-independence (colonial) era. Since after independence, we have had several home-grown public sector reforms and policies. But, what is worrisome is the fact that most of these reforms did not yield tangible results as the country still grapples with high rate of unemployment, poverty, insecurity, epileptic power supply, bad roads, ineffective rail system to mention but a few. Industry watchers have attributed the failure of the past public sector reforms to poor planning and implementation.

Irked by the mirage of problems still facing the country's public service despite past reforms, the Obasanjo administration (1999 -2007) and Yar'dua/Jonathan administration (2007 - 2013) came up with wide-ranging public service reform programmes aimed at repositioning the public service to effectively and efficiently deliver public goods and services. Notable among the reforms of the federal government of Nigeria in the last two decades are: Electoral Reform, Pension Reform, Public Procurement Reform, Banking Reform, Monetisation Policy, Service Compact with all Nigerians (Servicom), Public-Private Partnership (PPP), and National Economic and Empowerment Development Strategies (NEEDS).

\section{a. Pension Reform}

The new pension scheme, otherwise known as the Contributory Pension Scheme" is a product of the Nigerian Pension Reform. The scheme was conceived out of the need to solve the problem of increasing difficulties by government in meeting pension liabilities to its workers, both serving and retired. According to Professor Julius Ihonvbere, Special Adviser to former President Obasanjo on Policy and Programmes Monitoring, "despite efforts being made by the Federal Government to mop the pension backlog, it still owes about N2 trillion (naira) to its workers. He disclosed that the monthly pension bill of the Nigeria Railways stood at N250 million, with a monthly wage bill of N210 million, as against a paltry sum of income from the same source".

The objectives of the new pension scheme include among others to: ensure that every person who worked in either the Public Service of the Federation, Federal Capital Territory or 
Private Sector receives his retirement benefits as and when due; assist improvident individuals by ensuring that they save in order to cater for their livelihood during old age: and establish a uniform set of rules, regulations and standards for the administration and payments of retirement benefits for the Public Service of the Federation, Federal Capital Territory and the Private Sector.

\section{b. Public Procurement Reform}

There is no gain saying that effective and efficient procurement policy, procedures and practices by public bodies can have a significant impact on the accountability and value for money aspects of the purchase of goods and services by public sector organisations. The potential for real savings from more effective procurement policies and practices is significant. Achieving savings is important as it frees up resources which can be redirected to the provision of services within organisations. Under the new public procurement policy, public procurement process in public sector organisations is heavily decentralised to avoid sharp practices by officers charged with the procurement function. Public bodies perform the function independently within a framework of EU/national laws and national guidelines. These promote open and transparent competition as a means of achieving value for money. The increasing complexity and importance of purchasing decisions by public bodies calls for a more strategic focus and improved management of the public procurement process.

\section{c. Banking Sector Reform}

The Nigerian banking sector is one of the greatest beneficiaries of the public sector reform programme of the federal government. In the last two decades, the Nigerian banking sector has undergone wide-range drastic reforms aimed at restoring public confidence in the sector. The experience of the military era which led to the collapse of some commercial banks necessitated the need to reform the sector. Mergers and acquisitions are some of the fall-outs of the banking sector reform occasioned by the raise in the capital base for commercial banks to a minimum of $\mathrm{N} 25$ billion. Community banks and insurance companies were not left out; they all had their capital bases reviewed upwards to protect customers' funds. Today, an average depositor in Nigeria can sleep with their two eyes closed. Customers do not have to go to the banking hall with their mats and mattresses to make withdrawals. Round-tripping is now a thing of the past. Corporate governance, E-banking, internet banking, cashless economy, etc. are some of the deliverables of the banking sector reform.

\section{d. Monetisation Policy}

The monetisation policy is seen by many public officers as one of the best things to happen to the public workers in Nigeria. The policy came as a direct response to the huge amount of money being spent by government as a result of providing benefits in-kind for public officers, thereby freeing funds for capital expenditure. The policy also seeks to help public servants prepare for retirement by encouraging savings, reducing dependency syndrome and preventing sharp drop in standard of living after retirement.

The major by-product of the monetisation policy is what is now known as the consolidated salary structure for all cadres of public officers. Some benefits of the policy include the sale 
of government buildings and vehicles to public officers on the first-option of owner-occupier basis, thereby transforming public officers to property owners, and outsourcing of specialized services such as cleaning, gardening, security, etc. to private sector entities who specialize in the delivery of such services, allowing public officers to focus on their core function - policy implementation.

\section{d. Servicom}

Servicom the acronym for service compact with all Nigerians is a policy initiative aimed at achieving service excellence in public sector organisations. The policy was conceived against the backdrop of declining quality of public goods and services. Nigerians are believed to have been short-changed by public service providers most of whom cut corners. The servicom charter emphasises the need for public sector organisations to deliver what is promised and dealing with any problems, complaints and objections that arises thereafter. The key to service excellence is not only to focus on what services we provide, but how we deliver them. The bottom-line of the servicom initiative is to provide value for every 'kobo' spent by public sector institutions.

\section{f. Public-Private Partnership (PPP)}

Public-Private Partnership (PPP) is an arrangement between government and private sector entities to jointly provide public infrastructure, community facilities and related services for the benefit of Nigerians. The arrangement is characterized by sharing of investment, risk, responsibility and reward between the partners. Generally, these partnerships involve the financing, design, construction, operation, and maintenance of public infrastructure and services. The fulcrum of the PPP policy thrust is the need to harness the combined strengths of both the public and private sectors to establish complementary relationships, on the premise that both the public and private sectors have unique advantages in specific aspects of project service delivery.

\section{g. National Health Insurance Scheme (NHIS)}

In order to ensure that every Nigerian has access to good health care services, the National Health Insurance Scheme (NHIS) was launched. Under the scheme, the employee chooses and registers himself and his dependants with any Health Care Provider (HCP) approved by government (public or private). The employee has the right to change his HCP after a minimum of three months, if he is not satisfied with the services being given. The Health Maintenance Organisations (HMOs) are charged with the responsibility to make payment for services rendered to a contributor (employee) to the Health Care Provider. Some of the laudable objectives of the NHIS include to ensure full private sector participation in health care delivery; that every Nigerian has access to quality health care services; protect families from the financial hardship of huge medical bills; limit in the rise of cost of health care services, availability of funds to the health sector for improved services, etc.

\section{h. Privatization, Liberalization, and Deregulation (PLD) Policy}

The Privatization, Liberalization, Deregulation Policy was initiated in the early stage of the 
Obasanjo's administration to reduce government involvement in the provision of goods and services that can be better produced by the private sector. The policy also seeks to engender competition into markets and thereby improve efficiency and effectiveness in the provision of goods and services and allocation of resources

The privatisation, liberalization and deregulation policy initiative will unarguably contribute to reduce the financial burden on government as a result of the running costs of utilities and provision of subsidies, withdrawal of government from dominant role played in the economy, and results in a private-sector led economy. Some of the key components of the PLD policy include: Public-Private Partnerships; Build-Operate-Transfer; Rehabilitate-Operate-Transfer, Design, Build Operate and Transfer, etc. to attract private capital to key sectors like power, roads, and railways.

\section{i. National Economic and Empowerment Development Strategies (NEEDS)}

The National Economic and Empowerment Development Strategies (NEEDS) initiative is aimed at re-launching Nigeria into socio-economic transformation that will reposition it to take full advantage of its opportunities and potentials for the actualisation of sustained growth, development and prosperity. The policy is meant to facilitate the attainment of the United Nation's Millennium Development Goals (MDGs) aimed at addressing extreme poverty and hunger, eradication of illiteracy through access to quality universal basic education programme, promote environmental sustenability, provision of adequate shelter and promotion of gender equality. The same policy was launched in all the 36 states of the federation under the State Economic and Empowerment Development Strategies (SEEDS) programme.

\section{Performance Management}

Organisations are set up to achieve the set goals of the organisation, and to achieve these goals would require the establishment of a work culture that values and rewards performance. Modern organisations have since grown beyond playing undue emphasis on the 'annual ritual' called performance appraisal to entrenching a culture of performance management in the organisation. Performance management is a process (not an event) of creating a work environment or setting that develops and improves the capabilities of employees and of the organization to achieve its mission and vision. It is the organization's strategic plan that defines the context for performance management. Performance management in public sector organisations would require a holistic system of interrelating human resource components designed to create a customer-focused, results-oriented, motivated, accountable, creative and satisfied workforce.

The performance management system consists of seven components or elements - position management, compensation, recruitment and selection, orientation, on-going coaching and motivation, appraisal, and recognition, development or correction. Performance management is all about making sure that all activities and tasks performed in the organisation create value for both the organisation and the employees, and are coordinated, leveraged and channelled to meet the organisational objectives. Armstrong and Baron (in 
Umoh, 2012, NMR) define performance management as a "strategic and integrated approach to increasing the effectiveness of organisations by improving the performance of the people who work in them and by developing the capabilities of teams and individual contributors." All seven components work together as the performance management system to create value for each employee and the organization. Therefore, change in any one of these related areas can have implication for the performance of the entire system. Since the performance of the organisation is the ultimate, public sector organisations should adopt a culture of performance management systems which will not only help them to manage, integrate, and leverage the performance of all job holders, processes, interfaces and domains, but also serve as intervention strategies and techniques in all Ministries, Departments and Agencies (MDAs). Higher performing organizations align systems, structures and processes to support the achievement of the organization's mission, vision, values, strategic direction and goals.

\section{Setting and Monitoring Targets}

No organisation, public or private, can achieve improvement in the performance or competence of its work force without a culture of setting and monitoring targets. Target setting is essential to the growth process in an organization; one important means by which management measures performance of employees. Twenty-first century organizations are expected to use targets as a means of driving performance in the organisation. Target Setting forms an objective basis of directing actions, enhancing performance and achieving self-targets for individuals, groups and the organisation. The Setting of performance targets and objective evaluation of performance reflect current management practices which is a hallmark of modern progressive organisations. What then is target? Target is the specific and measurable accomplishment to be achieved within a specific time and under cost constraints.

When targets are set it is also expected that machineries are put in place to continuously monitor them. Monitoring is the regular observation and recording of working activities taking place in an organization. It is a process of routinely gathering information on all aspect of the job. Monitoring also involves reporting or giving feedback about the progress of a job to the job holder. Effective target monitoring will not only help to provide information needed to make improvement decisions on the job but will help maintain focus and minimize waste.

In setting targets for public service officials, Management by Objectives (MBO) approach can be adopted. MBO requires managing performance through objective setting and performance agreement. These objectives are to be set from the individual level, up to the levels of the organisation. It also involves open appraisal in which the appraiser and the appraisee meet together to agree on objectives. This is one of the most effective performance management systems widely practiced in most organisations.

\section{Performance Measurement}

Performance measurement is one of the components of performance management. In order to claim that performance has improved, there must be some sort of observable and measurable changes according to the standards or indicators that have been established. Measuring the performance of the job holder and that of other domains in the organisation, including the 
performance of the organisation, is perhaps the greatest performance management challenge faced by Nigerian public sector organisations, with the major problem being in selecting what to measure. What you cannot measure is difficult to manage; therefore managing performance in public sector organisations has been difficult due largely to lack of clear objectives, metrics, standard criteria and performance indicators. Performance can be measured either in terms of the organization's or individual's ability to attain set goals by using available resources in the most efficient manner or progress toward specific goals. The priority for performance measurement is to focus on quantifiable factors that are closely linked to the drivers of success in the organization. These factors are known as key Performance Indicators (KPIs). Once these indicators are identified, a way has to be found to measure them.

Some people tend to believe that it is not possible or rather it is difficult to set targets, least of all measure the performance of public officers whose main activities and deliverables are purely intangibles. To some extent, one would agree that it is more challenging to set targets and measure performance in the service industry, but it is certainly doable. The most common performance measures or indicators of performance measurement are: Time - Completion schedules, benchmarks and delivery dates; Quantity - Volume of works an employee accomplishes, e.g. number of pieces produced, number of calls taken, and number of customers attended to; Quality - Extent to which work, products or services meet standards, specifications or customer expectations; Cost - Amount of money spent to produce goods and services, usually in relation to the budget; Materials - The level of raw material utilization in production and wastages recorded. Other performance measures include percentage of rejects, number of complaints, customer approval ratings, adherence to Health and Safety standard, and attendance and absenteeism. Organisations that lack strategic management cannot develop proper performance measures and standards.

\section{Skills and Approaches To Serve The Public Service}

When skills are available, the goals of service delivery become wider and deeper. If we are to return to the basics of service while pursuing modern technological systems, there are four areas of priority that public service leadership must follow:

\section{Priority One: Serving from cradle to grave}

Stating the obvious, a nation is measured by the strength of its people. The relevance of the public sector is in its ability to reach out to serve the needs of the youth, the adult and the elderly in communities. In essence, public sectors must serve demands from the cradle to the grave. And, serve the needs of divergent and diverse customers. Seemingly, having the same gender, race, colour, or creed no longer takes precedence over the conditions of life itself. The challenge for the public sector today is how to customise our products and services to ensure positive outcomes? 


\section{Priority Two: Offering various services across all social infrastructure}

The social infrastructure of our societies today is designed by the needs of citizens. The standards of service delivery are measured through the sectors of health, education, transportation, and local councils that must meet the demands of a fragmented yet interdependent social fabric. Healthcare must meet the need for both quality healthcare solutions and those of a society in a hurry.

In our own Nigerian environment, the emphasis should be, how do we serve various income profiles? With a simultaneous need for safety, security and courtesy, how do we ensure quality services for all citizens?

\section{Priority Three: Serving across economic models}

As Nigerian economies liberalise, the service levels desired by citizens becomes increasingly important. The quality of our service is dependent not so much on the understanding of economics as it is on an understanding of the basic needs of the people living in different economic contexts.

For decades now, we have focused on the hardware of salvaging economies, and we have as a result, probably not done enough in inculcating an economy of character. The currency of character will serve any economic model as it will know the boundaries and the limitations of each model. Extending this argument further, the currency of character is driven by principles, governance and corporate social responsibilities. It is not driven by greed, callousness and self interest. No economy or nation, I would safely argue, can sustain its relevance and continued competitiveness without a strong emphasis on character. The testaments of the recent past would support this argument.

\section{Priority Four: Serving beyond the Predictable}

Today, the role of government extends to dealing with complex issues - some of which have the features of "wicked problems" (Ho 2008) - in the unpredictable context of the global economy and networked societies, where multiple players are acting simultaneously. Local problems can quickly become global problems (e.g. Boko Haram in northern Nigeria) and global problems can have a devastating impact for some countries (e.g. global financial crises and emerging food shortage).

The difficulty for the public service is that conventional structures, systems and practices were not conceived or designed to deal with complexity and uncertainty. Conventional practice has been to break down complicated problems into simpler tasks that can be tackled separately (Wagenaar 2007). This approach leaves government in a reactive position, unable to detect emerging patterns and unable to intervene ahead of time.

A different approach is needed. It starts by recognizing that complexity is part of the normal state of affairs (Haynes 2003). Complex problems cannot be solved by breaking them down into smaller pieces. They can only be addressed by looking at the whole system - they require a systemic approach. 


\section{Institutional Capacity Building}

Building the capacity to achieve public results starts by valuing and preserving existing capacities. Public institutions were built over long (sometimes very long) periods of time. They define how power is exercised in society. They create and grant rights. They delineate between private interests and collective interests and how they can be reconciled. They provide a solid foundation for good governance which includes a respect for the rule of law and public institutions; due process, including fairness, transparency and accountability for the exercise of powers and the use of public funds; and public sector values, including the expectation that public servants will exhibit integrity, probity and impartiality. Together, these factors contribute to building the institutional capacity of the state apparatus. They provide the starting point for the preparation of public servants and future public service leaders.

The work of public servants must be grounded in a deep understanding of public sector values and public sector principles. Public servants are especially responsible people - they are required to put the collective interest above their individual interest in all things and all circumstances. They are granted special privileges and special protection as the bearer of a special trust to help them to live up to the legal obligations of the office they hold, to resist politically partisan pressures and the temptation of corruption. Public servants should exhibit the behaviour expected of public organizations: by providing advice based on facts and evidence rather than personal preferences; acting with courage in abiding with the rule of law; and respecting conventions and traditions when encouraging reform.

Public organizations need public servants. They are institution builders - they understand the importance of public institutions as a collective instrument: to protect people against the abuse or arbitrary use of powers; to ensure that we can collectively do more and do it better than any one person could do (even the most enlightened, benign dictator). This is the foundation and the starting point to prepare future public sector leaders. Public officers have a responsibility to leave to future generations better institutions than the ones they inherited. These requirements have remained relatively constant over time. Public organizations should be expected to show a strong commitment to improving their performance and making government more productive, efficient and effective. They do so for public sector reasons: to ensure that taxpayers money is used to the fullest to achieve public results; and out of respect for citizens who deserve to be treated with respect, fairness and dignity.

Well-performing public organizations give special attention to service delivery, user satisfaction and the need for continuous improvements. They focus on sound governance that incorporates other sectors and actors. Within their means and their capacity, they make use of the power of modern information and communication technologies to reduce costs, reduce the number of intermediaries (and therefore the risks of corruption) and to open up new channels of communication between government and citizens. These factors contribute to building the organizational capacity of public agencies. Public organizations need strong managers; their role is more difficult than that of managers in the private sector. 


\section{Strategies for Improving Competence}

Performance Management Systems components are ultimately the primary means to align the efforts of public servants to MDAs' strategic plans, Public Service Reform Programme (PSRP) and MDGs. The performance excellence imperative requires public servants at all levels to have commitment and skills to coach others, tools to apply leadership learning, and policies that support leadership capacity development.

The Nigerian public service faces particular conditions and trends that may or may not be similar to public services elsewhere. Such factors determine the leadership requirements of successful public managers and conditions that limit leadership potential. Below are some of the key organizational factors for improving the competence of public service officials in Nigeria:

1. The need for succession planning. Succession planning serves as a means of grooming natural successors to senior officers who may be retiring in the near future. Identify talents and high flyer in the system and prepare them ahead of time. Except this is done, the public will continue to suffer capacity gaps which ultimate have implication for public sector performance.

2. The need to promote strategic thinking to drive reforms and change in the public service. A better public service requires well-trained public servants with the time to work on long-term strategy. For the public service, strategic thinking means thinking how the public service will do its job beyond the next electoral cycle.

3. Adoption of certain elements of New Public Management (NPM) against maintaining a status quo bureaucracy. The new pubic management denotes a shift in the principles of public sector management. It is about reinventing the role of government, its agencies, and the means by which services are delivered, and employment practices within public sector organisations. It about importing those values that make the private sector 'thick' into the management of public sector organisations.

4. Need to adopt results and outcomes based management. Results and outcomes based management is a programme and project life-cycle management approach to management that integrates strategy, people, resources, processes and measurements to improve decision-making, transparency and accountability. The approach focuses on achieving outcomes, implementing performance measurement, learning and adapting as well as reporting performance.

5. Dealing with capacity constraints that led to fear of delegating work. Most managers tend to believe that except they do the work themselves nobody can do it better. This is not always the case. The simple truth is that most of them do not know how to delegate, as such do not have confidence in their subordinates. Before you begin to delegate a piece of work to your subordinate, spend the next occasion to train him on the job.

6. Accountability enhancement. Accountability is a relationship based on obligation to 


\section{MInstitute Macrothink}

demonstrate, review, and take responsibility for performance, both the results achieved in light of agreed expectations and the means used.

7. Need for a human resources development strategy. The government should take responsibility for planning and overseeing the development of the necessary human resources. The strategies chosen should realistically reflect the needs and capacity of the country, and an adequate budget should be allocated.

8. Providing high impact, need-driven training interventions. The main reason for this is that most training provided to public servants is not need-driven. Any training interventions not borne out of a need are doomed to fail. Training should not be carried out just for the sake of it; it should aim to add value to the service delivery.

\section{Conclusion}

It has taken many years and much sacrifice to build our modern nation states and a great deal of commitment to build the civil societies that comprise them. Public administration has played an important role in building the institutional and organizational capacities to achieve public results and to serve the collective interest. Public administrators have much to be proud of. But this does not mean that our approaches should remain static. Building on the strength of their public institutions and organizations, governments are called upon to play a more dynamic, less certain role: one that integrates government authority and collective power to bring about results of high public value in the face of complexity.

Serving beyond the predictable requires new capacities, new insights and new knowledge that both complement and transform what has come before. These are required to assist governments and their host societies to anticipate, innovate and adapt. This will help them to reduce the magnitude and frequency of crises, mitigate negative impacts, seize opportunities and prosper in the face of an unpredictable world.

\section{Recommendations}

The following recommendations will help to improve the competence of public service officials in Nigeria:

1. Public Service Training Institutes (PSTIs) in the country be streamlined, connected and their new roles strengthened to provide management training and prepare staff for improved performance and productivity in current roles and to assume new responsibilities.

2. Establishment of Public Service Training and Leadership Development Centres (PSLDCs) to prepare senior managers, executives for a progressive career in leadership and governance.

3. Succession planning and mentoring. Forward mentoring (i.e. selecting soon-to- retire public service officials who share the organizations passion), and Reverse mentoring (choosing person in current office to mentor new and existing staff and functionaries) can go a long way to addressing the twin problems of skills gap and skills shortages in the public service.

4. Heads of PSTIs be given a higher degree of responsibility for the mobilization of 


\section{Macrothink}

Journal of Public Administration and Governance ISSN 2161-7104 2013, Vol. 3, No. 4

technical cooperation assistance to facilitate strategic networking and to implement programmes derived from sub-regional, Commonwealth and international consensus agreements.

5. That appropriate foundation or formal funding mechanisms are established to enable on-track career-based public service employees to access professional courses and qualifications at or through PSTIs.

6. Offering part-time and long-term contracts, performance contracts, partial week contracts and inter-firm or inter-government exchange programmes.

\section{Glossary}

Accountability: To acknowledge and assume responsibility for one's actions, decision, policies, etc.

Competence: The ability to do something well or effectively.

Delegation: To ask another officer (usually a subordinate) to act or make decision on your behalf.

Deregulation: To remove government controls and restriction in a particular area of business or service delivery.

Liberalization: Allowing private sector organisations freedom to import petroleum products, and engage in other businesses hitherto the exclusive preserve of government.

Monetisation: Paying money in place of benefits-in-kind to public officers.

Motives: Reasons why an officer could perform well on the job.

NMR: Nigerian Management Review; A journal of the Centre for Management Development (CMD).

Outsourcing: To hire and pay workers from outside the public service to do work for government or supply things.

Performance: How successful or how well a public servant does his job.

Performance Indicators: Units of measurement or values with which to ascertain public officers' performance on the job e.g. Skills, Knowledge, Attitude.

Policy: A plan of government used as a basis for decision making or for implementation of projects.

Privatisation: Total or partial sale of government ownership or interest in business to privately owned companies.

Public Service Officers: Used to mean the same as Civil Servants, Public Servants, Public Officers and all career officers of government other than legislators and political appointees. 
Reform: To introduce changes and improvements into the public service as a means of enhancing the performance of the sector.

Round-Tripping: A market manipulation practice by banks to inflate transaction volumes through the continuous and frequent purchase and sale of securities, assets or commodities.

Servicom: Service compact with all Nigerians. This is the federal government's quality improvement policy of achieving customer satisfaction and value for money.

Strategy: A set of plans, measures to improve the competence of public servants.

\section{References}

Bartram, D., Robertson, I. T., \& Callinan, M. (2002). Introduction: A Framework for Examining Organizational Effectiveness. In I.T. Robertson, M. Callinan, \& D.

Bartram (Eds.), Organizational Effectiveness: The Role of Psychology (p. 1-12). Chichester, UK: Wiley.

Boyatzis, R. (1982). The Competent Manager: A Model for Effective Performance. New York: John Wiley \& Sons.

Bueno, C. and Tubbs, S. (2004). Identifying Global Leadership Competencies: An Exploratory Study. Journal of American Academy of Business. Sep. 2004, 5(1/2), p. 80-87.

Gould-Williams, J. (2003). The Importance of HR Practices and Workplace Trust in Achieving Superior Performance: A Study of Public-Sector Organizations.

International Journal of Human Resource Management, 14:1 February, p. 28-54.

Haynes, P. (2003) Managing Complexity in the Public Services. Maidenhead, UK: Open University Press.

Ho, P. (2008) Governance at the Leading Edge: Black Swans, Wild Cards and Wicked Problems. Ethos 4, 74-79.

Ichniowski, C., Kochan, T.A., Levine, D., Olson, C., \& Strauss, G. (1996). What Works at Work: Overview and Assessment. Industrial Relations, 35(3), p. 299-333.

Klijn, E-H. (2008) Complexity Theory and Public Administration: What's New? Public Management Review, 10(3), 299-317.

McClelland, D.C. (1973). Testing for Competence Rather Than for Intelligence. American Psychologist, 28, p. 1-14.

Rao, T.V. (2000a). Human Resource Development - Concept and Background, Human Resources Development: Experiences, Interventions and Strategies, New Delhi: Sage Publications.

Rodrigues, L. L. R., \& Chincholkar, A. M. (2005). Benchmarking the HR Practices of an 


\section{Macrothink}

Journal of Public Administration and Governance ISSN 2161-7104

Engineering Institute with Public Sector Industry for Performance Enhancement. International Journal of Training and Development, 9:1, p. 6-20.

Simpson, B. (2002). The Knowledge Needs of Innovating Organizations. The University of Auckland.

Spencer, L. \& Spencer, S. (1993). Competence at Work: Models for Superior Performance. New York: John Wiley \& Sons, Inc.

Umoh, A. B. (2012). Performance management in the Nigerian public service. Nigerian Mangement Review Vol. 20. No. 1, $2-7$.

United Nations Industrial Development Organization. (2002). UNIDO Competencies. http://www.unido.org.

Virtanen, T, (200) Changing Competences of Public Managers: Tensions in Commitment. The International Journal of Public Sector Management, 13, 4, 333-341.

Wagenaar, H. (2007) Governance, Complexity, and Democratic Participation: How Citizens and Public Officials Harness the Complexities of Neighborhood Decline. The American Review of Public Administration, 37(1), 17-50.

Woodruffe, C. (1992). What is Meant by Competency? In: Sparrow, P.R., Boam, R., Eds. Designing and Achieving Competency. McGraw-Hill International.UK. 